\title{
Új nemzetközi népegészségügyi dokumentumok, 2016
}

New international documents on public health, 2016

\author{
Szerzők: Csizmadia Péter $\bowtie$, Vitrai József \\ Nemzeti Egészségfejlesztési Intézet
}

Beküldve: 2017.01.31.

doi: $10.24365 /$ ef.v58i1.133

Kulcsszavak: népegészségügy, egészségfejlesztés, fenntarthatóság, Ottawai Charta, globalizáció

Keywords: public health, health promotion, sustainability, Ottawa Charter, globalization

2016 végén az Ottawai Charta kibocsátásának 30. évfordulója alkalmából több jelentős, az egészségfejlesztést érintő dokumentumot fogadtak el világszerte. A Népegészségügyi Szervezetek Világszövetsége (World Federation of Public Health Associations, WFPHA), kibocsájtotta a Charta a Világ Lakosságának Egészségéért dokumentumot. ${ }^{1} \mathrm{Az}$ Európai Népegészségügyi Szövetség (European Public Health Association, EUPHA) konferenciát tartott, ahol a Bécsi Nyilatkozatot tették közzé. ${ }^{2}$ Az Egészségügyi Világszervezet (World Health Organisation, WHO) és a Kínai Népköztársaság Nemzeti Egészség és Családtervezési Bizottsága által Shanghajban közösen megrendezett 9. Nemzetközi Egészségfejlesztési Konferencia elfogadta a Sanghaji Nyilatkozatot. ${ }^{3}$ Az említett dokumentumok javaslatokat fogalmaznak meg a népegészségügy számára korunk új kihívásai közepette. E dokumentumokkal egy időben jelent meg az Egyesült Királyság Egészségügyi Szolgálatának (National Health Service, NHS) a Kiáltvány az egészséges és egészséget teremtő társdalomért címú dokumentuma, ami ugyancsak hasznos lehet a hazai népegészségügy fejlesztése szempontjából. ${ }^{4}$

1986-ban az első Nemzetközi Egészségfejlesztési Konferencia elfogadta az azóta is irányadó Ottawai Chartát, amely egy erőteljes válasz volt a népegészségügy megújítására irányuló igényekre. A Charta alapul szolgált több későbbi fejleményhez, például az Egészségügyi Világszervezet Egészséget mindenkinek 2000-re és azon túl szakpolitikájának megvalósításához, az Egészséget minden szakpolitikában szemléletmód kialakításához, különböző, például az épített környezet és a közösségi egészségfejlesztés érdekében megvalósuló beavatkozások megvalósítása, illetve a prevenció fontosságának és az egészségbeli esélyegyenlőségnek a kihangsúlyozása során. Az Ottawai Charta alapelvei ugyanolyan fontosak, mint korábban, de 1986-hoz képest természetesen rengeteg változás történt, új kockázatok és lehetőségek állnak a népegészségügy előtt.

A változó helyzet, amelyre a Charta a Világ Lakosságának Egészségéért című dokumentum reagálni kíván, röviden a globalizáció fogalmával írható le, értve alatta, hogy az emberek, a pénz, a javak, új ideák egyre nagyobb távolságra való mozgása drámai mértékben felgyorsult. Ez számos lehetőséget rejt magában, hiszen a gazdasági, technológiai fejlődés hozzájárulhat a betegségek terheinek globális méretű csökkentéséhez. A globalizáció kihívásokat is hordoz. A károk, amelyeket az emberi tevékenység okoz a bolygónknak, ma már vitathatatlanok. $\mathrm{A}$ legújabb adatok szerint az emberi tevékenységhez köthető klímaváltozás elérheti azt a szintet, ahonnan már nem visszafordítható. A természeti erőforrások kiaknázásakor nem veszik figyelembe az okozott károkat, vagy azt, hogy a természeti kincsekkel 
kapcsolatos konfliktusok hátráltatják a társadalmi fejlődést.

Az Ottawai Charta óta eltelt években a fejlett ipari országok túlzottan a szabadkereskedelem elveinek érvényesítésére törekedtek anélkül, hogy az egészség és a jóllét, vagy a társadalmi javakba való befektetés fontosságát figyelembe vették volna. Ennek eredményeként a vagyon és hatalom folyamatosan multinacionális vállalatok, illetve néhány személy kezében koncentrálódott. A munka világában a bérek csökkentek és a munkakörülmények romlottak a gazdag országokban, míg a migráció meggyengítette az emberi erőforrásokat a szegényebb országokban. Szélesednek az országokon belüli és az országok közötti pénzügyi, oktatási és egészségbeli egyenlőtlenségek, fenyegetve a békét és a társadalmi kohéziót.

A helyzet mára fenntarthatatlanná vált. Az emberiségnek számos egymással összefüggő, a létet fenyegető kihívással kell szembenéznie. Az ember által okozott globális felmelegedés folytatódik, hozzájárulva aszályokhoz, éhínségekhez, áradásokhoz és egyéb természeti katasztrófákhoz. Korábban még nem látott számú népesség kelt útra, egy részük az országokon belül az egyre gyorsuló urbanizáció részeként, más részük fegyveres konfliktusok miatt kényszerült elhagyni lakóhelyét, de a legnagyobb részük a szegénység és a kizsákmányolás, a háború elől menekül, számos esetben a klímaváltozással összefüggő katasztrófák miatt. A javak és emberek fokozott mozgása a nem megfelelő kormányzati rendszerekkel párosulva elősegítette új fertőző betegségek felbukkanását és terjedését, beleértve az antibiotikum-rezisztenciát. A fegyverek elterjedése akár extrém csoportok kezében, akár instabil rendszerek körében, amelyek nukleáris fegyverekre tesznek szert, a világ biztonságát fenyegetik.

Hatalmi aszimmetria alakult ki egyrészről a globális erők és a befolyásos egyének, másrészről a helyi közösségek között, amely az Ottawai Karta hatalommal felruházni a közösségeket, hogy birtokosai és irányítói legyenek saját törekvéseiknek és sorsuknak felhívását egyre kevésbé teszi elérhetővé. Ezek a kihívások, amelyekkel a nyilatkozatok foglalkozni kívánnak.

\section{SANGHAJI NYILATKOZAT}

A Sanghaji Nyilatkozat az Egészség Fejlesztéséről a Fenntartható Fejlődés 2030-ig Tervezett Megvalósításában így foglalható össze:

- A résztvevők kijelentették, hogy az egészség és a jóllét nélkülözhetetlen az ENSZ Fenntartható Fejlődés Célok (FFC) eléréséhez. Megerősítették, hogy az egészség univerzális jog, közös társadalmi cél, politikai prioritás. Az FFC az egészségbe történő befektetés, valamint minden életkorú egyénre kiterjedő egészségbiztosítás és az egyenlőtlenségek csökkentésének kötelezettségét írja elő.

- A résztvevők kijelentették, hogy egészségfejlesztési tevékenységet végeznek valamennyi FFC eléréséhez. Ehhez az egész társadalom részvétele szükséges. Megvalósítható, gyakorlatias, igazoltan nagy hatású, az Ottawai Charta nyomán kialakított stratégiára van szükség. Valamennyi befolyásoló tényezőre kiterjedő beavatkozásokra, az embereknek az egészségük feletti kontrollt biztosító és egyénközpontú egészségügyi rendszerre van szükség.

- A résztvevők kinyilvánították, hogy az egészség érdekében erőteljes politikai döntéseket tesznek. Megállapították, hogy az egészségfejlesztés globalizálódott, az egészségbiztonságot veszélyezteti a növekvő és erős kereskedelmi vállalatok tevékenysége. A globális egészségkockázatok megjelenése integrált válaszokat igényel. A méltánytalan egészségbeli egyenlőtlenségek különböző ágazatokban és régiókban globálisan is koordinált politikai akciókat tesznek szükségessé, a nőkre és a menekülő tömegekre kiterjedően, akik humanitárius és környezeti krízisek miatt hagyták el lakóhelyüket.

- A résztvevők nyomatékosították, hogy a városok és közösségek az egészség szempontjából döntő jelentőségű színterek. A lakókörnyezetek és közösségek kiemelt szerepét hangsúlyozták az egészség létrejöttében. Az egészség az egyik leghatékonyabb elem a városok fenntartható fejlődésében.

- A résztvevők kiemelték az egészségmúveltség jelentőségét a képessé tevés és az igazságosság elérésében. Nemzeti és helyi stratégiák szüksége- 
sek az egészségműveltség fejlesztésében a társadalom minden csoportjában és minden oktatási szinten.

- A résztvevők közös cselekvésre buzdítottak. A deklaráció elfogadói hangsúlyozták, hogy az egészség politikai döntés, és hogy minden olyan érdek ellen fellépnek, amely hátrányos az egészségre és minden akadály eltávolítását támogatják a képessé tevés útjából.

\section{BÉCSI NYILATKOZAT}

Az Európai Népegészségügyi Szövetség Bécsi Nyilatkozata megerősítette elkötelezettségét az Ottawai Charta alapelvei felé. Csatlakozott a Sanghaji Nyilatkozathoz, valamint a Charta a Világ Lakosságának Egészségéért c. dokumentumban leírtakhoz. Ezen túl, az egészség alapfeltételeit illetően az Ottawai Chartához az alábbi kiegészítéseket fúzte:

- Helyi, nemzeti, regionális, globális irányításra van szükség, amely nyitott és átlátható, demokratikus, és a teljes népesség érdekeit képviseli.

- A szociális gondoskodás magas szintjére képes ellátórendszerek létrehozása mindenki számára elengedhetetlen.

- Jó minőségú munkára, tisztességes foglalkoztatáspolitikára és biztonságos munkafeltételekre van szükség az egészségfejlesztésben.

- Optimális körülmények biztosítása, szerető, támogató, befogadó, ösztönző környezet biztosítása szükséges a korai gyermekkorban.

\section{CHARTA A VILÁG LAKOSSÁGÁNAK EGÉSZSÉGÉ- ÉRT}

A Charta a Világ Lakosságának Egészségéért egy konzultációs folyamat eredményeként jött létre, melynek során több mint 100 népegészségügyi szervezet véleményét kérték ki, többek között a WHO-ét is.

A politika felismerte, hogy az egészség a növekedés, a fejlődés, az igazságosság és a stabilitás alapvető feltétele. Az egészséget különböző kormányzati szintek komplex és dinamikus viszonyai határozzák meg. A kormányoknak figyelembe kell venniük a szociális, környezeti és viselkedési tényezők szerepét, beleértve a gazdasági feltételeket, az életkörülményeket, a demográfiai változásokat és az egészségtelen életmódot.

Mindezek alapján indokoltnak látják a globálisan változó társadalmi-politikai feltételek között áttekinteni a népegészségügy szerepét. Helyzetelemzésük szerint a valóságban széttagoltak, eltérőek és hiányosak a népegészségügyi szolgáltatások, tevékenységek, nincs egyetértés abban, milyen szolgáltatások, tevékenységek szükségesek, nincs közös szótár, ami akadályozza a népegészségügyi rendszerek eredményességét, beleértve a biztonság, a szakemberképzés, a minőségi standardok kialakítását. A népegészségügyi szakpolitikák - főként a betegségspecifikusak - vertikálisak maradtak.

A konzultációk eredményét a Szövetség az alábbiakban foglalja össze:

- Valódi politikai elköteleződés szükséges, hiszen a politikusok gyakran csak a szavak szintjén foglalkoznak a népegészségüggyel.

- Az erőforrásokat a befolyásoló tényezőkre kell fordítani - fenntartható, átlátható módon.

- Figyelembe kell venni az ideológiák hatását.

- Korszerúbb és megbízhatóbb egészségi adatok szükségesek.

- Multiszektoriális és holisztikus megközelítés szükséges, ennek eléréshez széleskörü egyeztetést és a megközelítéssel összhangban lévő döntés-előkészítést kell megvalósítani a népegészségügyben.

- A WHO-nak kell a vezető szerepet felvállalnia.

- A népegészségügyben új vezetőkre van szükség.

- A kormányzatok befolyásolásához megfelelő koncepció szükséges.

- Új, kreatív megoldások kellenek.

- Sikeres népegészségügy által megvalósított példákra van szükség.

- A "know-do gap", vagyis a tudás és a gyakorlat közötti eltérés áthidalása szükséges, hiszen, annak ellenére, hogy a multiszektoriális megközelítési mód egyre gyakoribb a népegészségügyben, még semmi esetre sem tekinthető elfogadott formának. 
A felhívás a népegészségügy számára meghatározza az un. alapszolgáltatásokat (egészségvédelem, megelőzés, egészségfejlesztés), illetve az alaptevékeny- ségeket (irányítás, érdekképviselet, kapacitás és információbiztosítás). Ezek kapcsolatát az 1. ábra szemlélteti:

\section{1. ábra: A népegészségügy alapszolgáltatásai és alaptevékenységei}

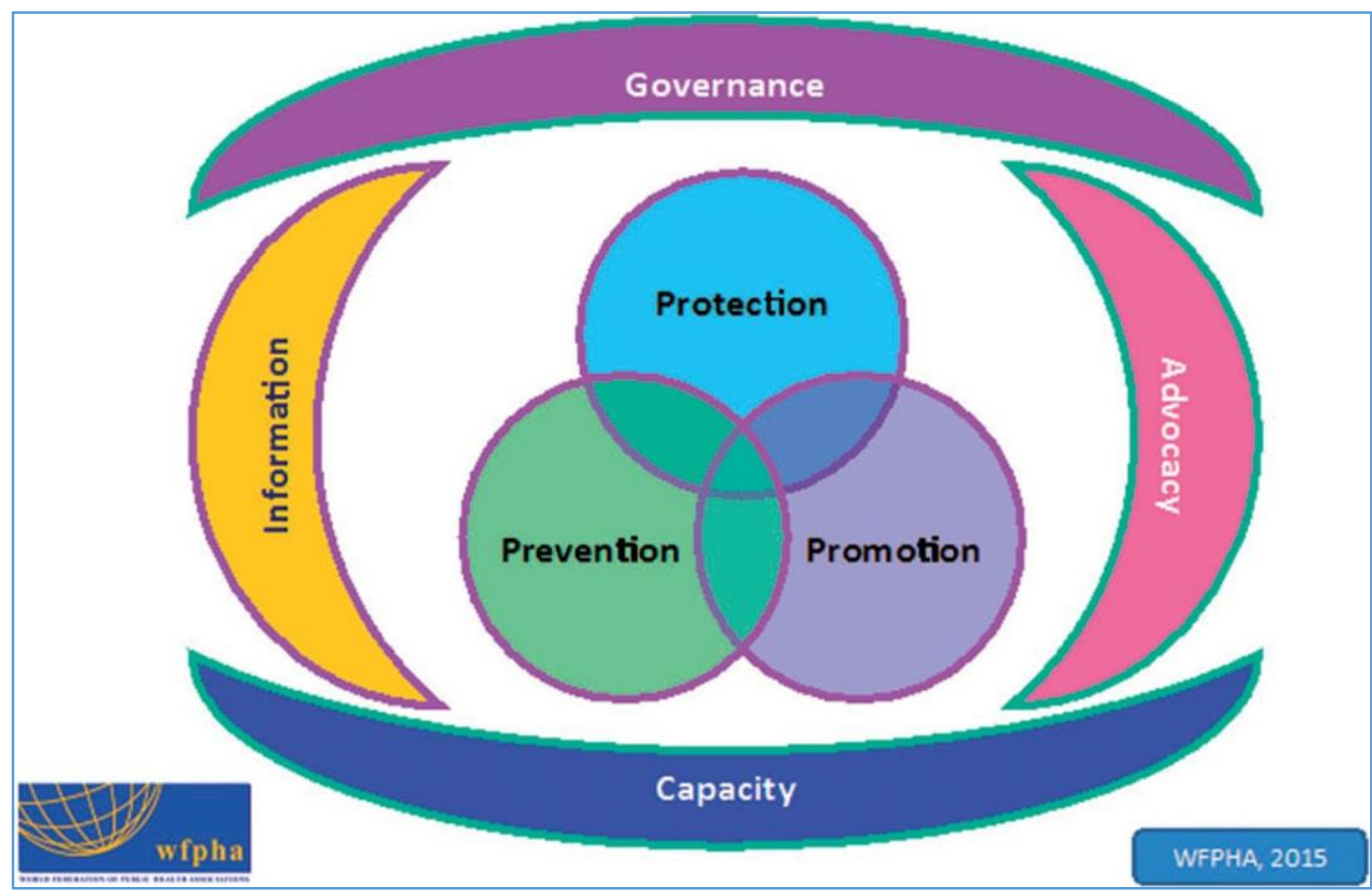

Forrás: A Global Charter for the Public's Health - the public health system: role, functions, competencies and education requirements; doi:10.1093/eurpub/ckw011

Az átfedések a szolgáltatások és tevékenységek között elsősorban az egészségfejlesztés, a primer prevenció és a környezetegészség területén léteznek.

A népegészségügyi alapszolgáltatásokat és alaptevékenységeket a Charta az alábbiak szerint értelmezi:

- Egészségvédelem: nemzetközi egészségügyi szabályozás és együttmúködés; egészséghatás vizsgálat; fertőző betegségek megfékezése; felkészülés vészhelyzetekre; foglalkozás-egészségügy; környezetegészségügy, klímaváltozás és fenntarthatóság;

- Megelőzés: primer prevenció: védőoltások; másodlagos prevenció: szúrés; harmadlagos prevenció: bizonyítékalapú, közösségre alapozott, integrált, személyközpontú, minőségi ellátás, rehabilitáció; ellátás szervezés-tervezés;
- Egészségfejlesztés: egyenlőtlenségek; környezeti meghatározók; társadalmi és gazdasági meghatározók; ellenálló képesség; magatartás és egészségmúveltség; életút megközelítés; egészséges színterek;

- Irányítás: népegészségügyi szabályozás; egészségügyi és interszektoriális szakpolitikák; stratégia; finanszírozás; intézményrendszer; minőségbiztosítás: átláthatóság, elszámoltathatóság, auditálás;

- Információ: adatgyűjtés, monitorozás és értékelés; befolyásoló tényezők monitorozása; kutatás és bizonyítékok; kockázat és innováció; közreadás és átvétel;

- Érdekképviselet: vezetés és etika; egészségbeli igazságosság; társadalmi mobilitás és szolidaritás; lakosság oktatása; emberközpontúság; önkéntes közösségi szektor bevonása; kommunikáció; fenntartható fejlődés; 
- Kapacitások: munkaerő fejlesztés a népegészségügyben, az egészségügyben és kapcsolódó ágazatokban; munkaerő tervezés: létszámok, erőforrások, infrastruktúra; standardok, tantervek, akkreditáció; képességek, oktatás, tréning.

A Charta a globális és nemzeti népegészségügyi rendszer fejlesztése érdekében az alábbi ajánlásokat fogalmazza meg:

1. Konszenzus: a globális népegészségügy közösen értelmezett és a WFPHA által elfogadott fogalmának meghatározása, amely az oktatás és képzés alapját képezi.

2. Koordináció: a WFPHA elismeri és támogatja a WHO vezető szerepét a globális népegészségügyben a multiszektoriális dialógusok, a koordináció és a döntéshozatal előmozdításában.

3. Vezetés: a népegészségügy vezető szerepe megerősítendő, hogy a Charta beépüljön az ágazatközi és az egészségügyi szakpolitikába és kormányzati múködésbe, építve és megerősítve a meglévő koncepciókat.

4. Munkaerő: a népegészségügyi munkaerőnek a Charta szolgáltatásokra, tevékenységekre, szakpolitikákra vonatkozó iránymutatása alapján történő fejlesztése a globális egészségbiztonság és egészségügyi rendszer fenntarthatósága érdekében.

5. Eszközök és alkalmazások: esettanulmányokat, standardokat kellene elóálítani, hogy példát lehessen mutatni a Charta globális és nemzeti szinten történő alkalmazására, az oktatás és képzés számára.

6. Erőforrások: a Charta megvalósításához politikai elkötelezettség, valamint a partnerek és a donorok koordinált támogatása szükséges.

\section{KIÁLTVÁNY AZ EGÉSZSÉGES ÉS EGÉSZSÉGET TE- REMTŐ TÁRSADALOMÉRT}

Szintén az elmúlt év végén a Lancet folyóiratban tették közzé a Kiáltvány az egészséges és egészséget teremtő címú dokumentumot ${ }^{4}$, amelyben a brit NHS szakemberei ismertették törekvéseiket.

Ezek közül az alábbi célkitűzéseket tartjuk fontosnak kiemelni:
2. célkitűzés:

Az egészségügyi ellátórendszer átalakítása: a kórház- és betegségközpontú ellátás helyett, a személy- és egészség központú ellátás kialakítását fel kell gyorsítani és forrásokat biztosítani hozzá.

Szükséges az otthoni és közösségközpontú ellátás fejlesztése, az új technológia fokozottabb használata, új partnerek, szolgáltatók bevonására és egy újfajta infrastruktúra kifejlesztésére. A törekvések támogatására a szerzők jelzik, hogy az ENSZ egyik illetékes bizottsága szerint egy társadalom egészségi állapota nagymértékben hozzájárul a gazdasági fejlődéshez, illetve az egészségbe való befektetésnek a legmagasabb a megtérülési rátája.

\section{3. célkitűzés:}

A gazdaság minden szereplőjét és a népesség szélesebb köreit bevonva olyan tervet kell kifejleszteni és alkalmazni az egészséget teremtő társadalom felépítésére, amely az egészség-egyenlőtlenségek megszüntetését célozza.

A jelenlegi gyakorlat az egészségfejlesztés és a prevenció területén túl partikuláris, elaprózott, ezért egy jóval szélesebb össztársadalmi megközelítésre van szükség.

4. célkitúzés:

Az Egyesült Királyság egészségügyi, ellátó és tudományos intézményeinek támogatni kellene az egészséges társadalom kialakítását, helyreállítását.

Összefoglalva: a dokumentumok kiemelik a népegészségügy felelősségét abban, hogy a változások szószólójává váljon az érdekhordozókkal együttműködve, a népegészségügyet támogatókkal közösen, egyben vállalva a konfrontációt az ellenzőivel, továbbá abban, hogy a kormányzatokat és más szereplőket igyekezzen rávenni az egészség támogatására. Kiemelik a célok megvalósításához szükséges kapacitásépítés fontosságát, a kutatókra, a gyakorlati szakemberekre és az informatikai háttérre vonatkozóan.

A jelenlegi széttagolt, ingatag és hiányos népegészségügyi ellátások helyett rugalmas népegészségügyi rendszerekre van szükség, helyi és globális szinten.

Sürgetik a nemzetközi megegyezést a népegészségügyi ellátások és tevékenységek pontos tartalmáról, 
valamint a közös, pontos szakmai fogalmak létrehozását, amelyek pozitív irányba befolyásolják a népegészségügyi szervezetrendszer erőfeszítéseit. A dokumentumok koncepcionális keretként szolgál- hatnak, amely a népegészségügyi szervezetrendszer számára lehetővé teszi a globális kommunikációt, a kapacitások racionális felhasználását, és a teljesítmény javítását, átgondolt beavatkozások révén.

\footnotetext{
${ }^{1}$ A Global Charter for the Public's Health - the public health system: role, functions, competencies and education requirements; doi:10.1093/eurpub/ckw011

2 https://ephconference.eu/repository/publications/Vienna Declaration final version update28112016.pdf (Elérve: 2017. január 26.)

${ }^{3}$ Shanghai Declaration on promoting health in the 2030 Agenda for Sustainable Development; http://www.who.int/healthpromotion/conferences/9gchp/shanghai-declaration.pdf?ua=1 (Elérve: 2017. január 26.)

${ }^{4}$ N. Crispet al.: Manifesto for a healthy and health-creating society, Lancet 2016; 388: e24-27; http://dx.doi.org/10.1016/S0140-6736(16)31801-3
} 